Citation: Kam, E , Önce, M . "Pollution Potential of Heavy Metals in The Current Sea Sediments Between Bandirma (Balikesir) and Lapseki (Çanakkale) in the Marmara Sea". Journal of Engineering Technology and Applied Sciences 1 (3) 2016 : 141-148

\title{
POLLUTION POTENTIAL OF HEAVY METALS IN THE CURRENT SEA SEDIMENTS BETWEEN BANDIRMA (BALIKESİR) AND LAPSEKİ (ÇANAKKALE) IN THE MARMARA SEA
}

\author{
Erol Kama*, Melike Önce ${ }^{b}$ \\ ${ }^{a}$ Yildiz Technical University, Faculty of Arts and Sciences, Physics Department, Davutpaşa \\ Campus, 34220 Esenler, Istanbul, TURKEY, \\ erolkam@yildiz.edu.tr*(corresponding author) \\ ${ }^{b}$ Yamık Kemal University, Çorlu Engineering Faculty, Environmental Engineering \\ Depertmant, 59860 Çorlu, Tekirdă̆, TURKEY, \\ melike-once@hotmail.com
}

\begin{abstract}
The aim of this study was to investigate the concentration of heavy metals on Holocene sediments in the Southwest Marmara Sea. Accordingly, ten core samples were collected in the investigate area. Heavy metal analyzes were performed using ICP-OS device. In the samples, 28 heavy metal (Fe, $\mathrm{Zn}, \mathrm{Al}, \mathrm{Mn}$, As, B, Co, Cr, Cu, Ni, Sb, Na, Mg, K, Ca, P, Pb, Hg, Cd, Mo, Pb, Pt, Sn, Se, Hg) concentrations were determined. Comparing the results of the analysis are with World Average Shale Values, max values for $\mathrm{Ni}, \mathrm{Mn}, \mathrm{Cr}, \mathrm{Zn}$ and $\mathrm{Co}$ were above the World average values. Maximum and minimum $\mathrm{Pb}, \mathrm{Cu}$ and Fe values are below the mean shale values. The Co concentration was determined above the mean values for both values. Also, the concentrations of heavy metals in the samples taken from the Kor-9 site were at the lowest values compared to other locations. It was seen that there are no settlements, industrial establishments or maritime structures like such as a port in this locality. In places where values are high, wastewaters were originated from settlements, harbor and industrial wastes. These findings indicate that the most important cause of heavy metal contamination is anthropogenic causes.
\end{abstract}

Keywords: Heavy metal, sediment geochemistry, Marmara Sea, Bandirma, Lapseki

\section{Introduction}

One of the main causes of environmental pollution today is the uncontrolled release of heavy metals. Toxic effects on living beings and bioaccumulation have increased the studies carried out on heavy metals. Heavy metals mix with domestic and industrial pollutants and natural resources into water environments. They also migrate to the aquatic environment with the 
decomposition of soils and hence heavy metals in the composition of soil by acid rains. Thermal waters and agricultural activities are other causes of heavy metal pollution. Chemical fertilizers, especially used in agricultural activities, cause pollution in the receiving environment due to heavy metals such as $\mathrm{Cd}, \mathrm{Ni}, \mathrm{Cr}$. The presence and amount of these metals in phosphorus fertilizers depends on the metal content of the raw rock phosphate [1].

The heavy metals transported to the water dilute to an extreme degree and partly form solid compounds as carbonates, sulphates, sulfur and sink to the basin, and become enriched in this region. In sea water, metals are physically are found in four basic forms as dissolved in water, colloid particles, in the living organisms and on other colloid particles [2]. Since the adsorption capacity of the sediment layer is limited, the concentration of heavy metals in the water is constantly increasing $[3,4]$.

Especially in the Marmara Sea, pollution is increasing in recent years as a result of industrial activities and rapid population growth. The study area is a region where both tourism and industrial activities are concentrated [5].

There are studies carried out in the Marmara Sea, Aegean Sea, Black Sea and Mediterranean Sea, which are focused on the pollution that heavy metals made in previous years in aquatic environment.

Algan et al. (1999) observed heavy metal pollution using marine sediments in the study conducted in the Bosphorus [6]. Yümün (2016) determined heavy metal pollution in the Çanakkale Strait using bioindicators (Foraminifera). In the study, it was determined that the number of Foraminifera was low in the areas where heavy metal concentrations were concentrated and that the number of Foraminifera was very high in other regions [7]. Balk1s and Çağatay (2001) investigated heavy metal distributions and sources of Erdek Bay sediments in the Marmara Sea by geochemical analyzes [8] . Erdoğan (2009), in their doctoral dissertation, observed and statistically evaluated heavy metal pollution in ICP-MS in Izmir Gulf sediments [9] . Yümün et al. (2016a) determined heavy metal concentrations in current sea sediments in Izmir Gulf and examined the effect of this pollution on foraminifera [10].Ünsal et al. (1998) identified terrestrial sources of $\mathrm{Hg}, \mathrm{Cu}, \mathrm{Pb}, \mathrm{Cd}$ and $\mathrm{Zn}$ in the Black Sea sediment samples [11]. Yümün et al. (2016b) determined the distribution of heavy metal concentrations in the vertical direction by using the elemental analysis method in the lake sediments in the study conducted at Kulakçayırı Lake (Arnavutköy / Istanbul) which is located on the coast of the Black Sea. Analyzes made by examining the drilling cores show that the concentrations of heavy metals are low at the base and high at the upper levels [12].

This study was carried out to determine heavy metal concentrations in current sediments in the southwest of the Marmara Sea. In addition, this study will form the basis for all studies aiming at ecological pollution analysis. The study will set an example not only for the Marmara Sea, but also for other lakes and seas.

\section{Materials and method}

The study area covers the marine area between Bandırma (Balıkesir) and Lapseki (Çanakkale) on the southwest of Marmara Sea. The study area location map and sample coordinates are given in Fig. 1 and Table 1. Core samples were taken from ten different locations from the study area. 


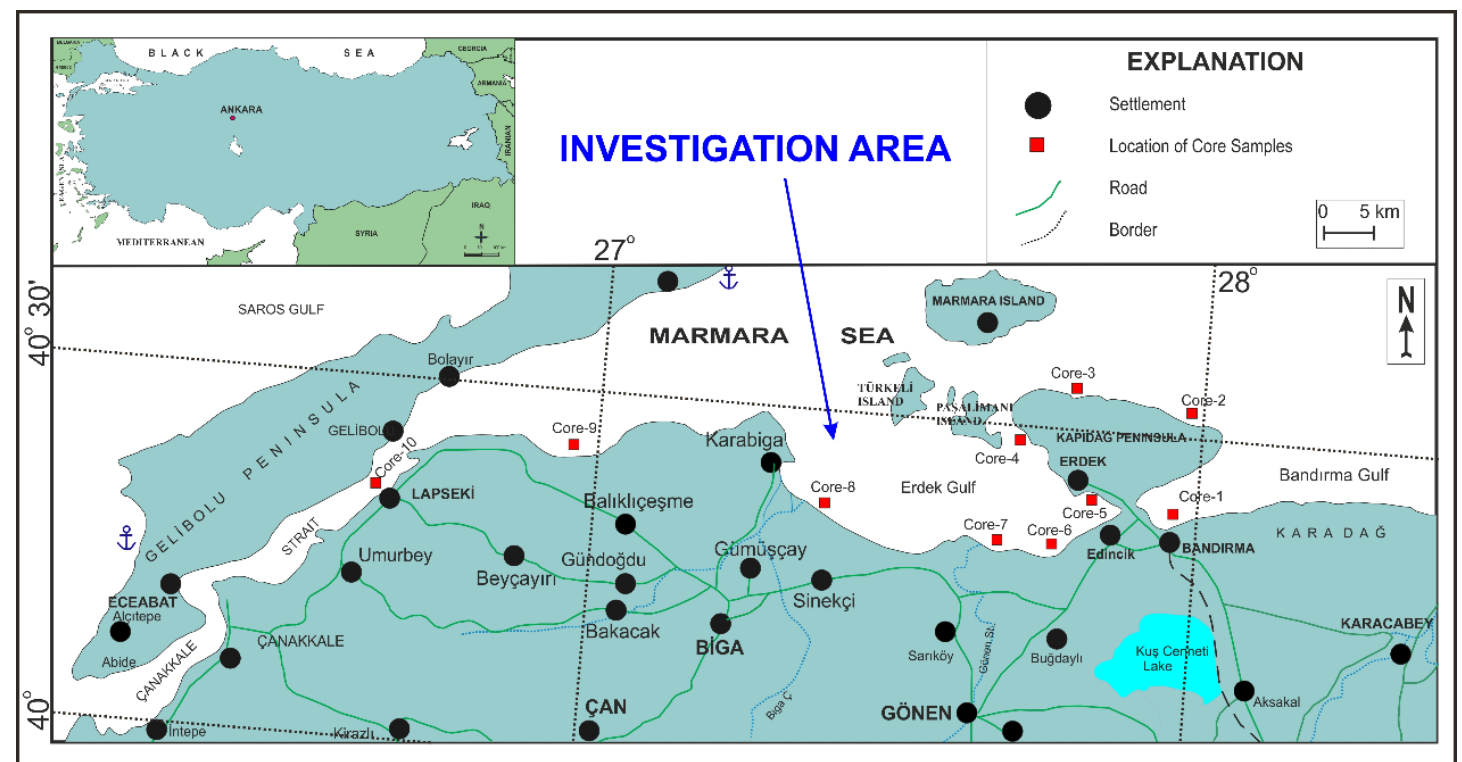

Figure 1. Location Map of Investigation Area

For heavy metal analysis, $15 \mathrm{~g}$ samples were prepared by separating $10 \mathrm{~cm}$ sections from the core samples and geochemical analyzes were made. Analyses for 28 heavy metals (Fe, Zn, Al, $\mathrm{Mn}, \mathrm{As}, \mathrm{B}, \mathrm{Co}, \mathrm{Cr}, \mathrm{Cu}, \mathrm{Ni}, \mathrm{Sb}, \mathrm{Na}, \mathrm{Mg}, \mathrm{K}, \mathrm{Ca}, \mathrm{P}, \mathrm{Pb}, \mathrm{Hg}, \mathrm{Cd}$, , Pb, Pt, Sn, Se, Hg) were carried out at Namik Kemal University Scientific and Technological Research Application and Research Center (NABIL TEM). Sediment samples are dried and pounded using mortar and the granules are separated and $0.5 \mathrm{gr}$ is taken from this sample. The collected samples are placed in incineration tubes and burned for 1 hour at $98^{\circ} \mathrm{C}$ and 1.5 hours at $200^{\circ} \mathrm{C}$ by adding $12 \mathrm{~mL}$ $\mathrm{HNO}_{3}$ and $4 \mathrm{~mL} \mathrm{HCl}$. After the lids of the cooling tubes are pulled out in the furnace, it is completed to $50 \mathrm{~mL}$ with ultrapure water and filtered using filter papers. Geochemical analyses of these samples were performed using ICP-OS device.

Table 1. The cordinates of heavy metals

\begin{tabular}{|c|c|c|c|}
\hline \multirow{2}{*}{$\begin{array}{l}\text { Core } \\
\text { Sample No }\end{array}$} & \multicolumn{2}{|c|}{ Coordinate (WGS-84, $6^{0}$ ) } & \multirow{2}{*}{$\begin{array}{c}\text { Depth } \\
\text { (m) }\end{array}$} \\
\hline & Y (East) & X (North) & \\
\hline Core-1 & $577913.27 \mathrm{~d} D$ & $4469930.41 \mathrm{~m} \mathrm{~K}$ & 15 \\
\hline Core-2 & $585045.49 \mathrm{~d} D$ & $4483970.83 \mathrm{~m} \mathrm{~K}$ & 17 \\
\hline Core-3 & $570948.96 \mathrm{~d} D$ & $4487049.25 \mathrm{~m} \mathrm{~K}$ & 11 \\
\hline Core-4 & $558656.27 \mathrm{~d} \mathrm{D}$ & $4484873.57 \mathrm{~m} \mathrm{~K}$ & 19 \\
\hline Core-5 & $566071.70 \mathrm{~d} \mathrm{D}$ & $4472515.16 \mathrm{~m} \mathrm{~K}$ & 22 \\
\hline Core-6 & $571961.37 \mathrm{~d} \mathrm{D}$ & $4469752.91 \mathrm{~m} \mathrm{~K}$ & 10 \\
\hline Core-7 & $564647.99 \mathrm{~d} D$ & $4463344.42 \mathrm{~m} \mathrm{~K}$ & 25 \\
\hline Core- 8 & $531858.68 \mathrm{~d} D$ & $4469137.26 \mathrm{~m} \mathrm{~K}$ & 27 \\
\hline Core-9 & $499496.99 \mathrm{~d} \mathrm{D}$ & $4472122.64 \mathrm{~m} \mathrm{~K}$ & 18 \\
\hline Core-10 & $471895.62 \mathrm{~d} D$ & $4466148.95 \mathrm{~m} \mathrm{~K}$ & 20 \\
\hline
\end{tabular}




\section{Findings}

The sedimentary structure of the study area is largely tin and clay [13]. In terms of hydrographic properties and $\mathrm{pH}$ values, it exhibits general characteristics of the Marmara Sea $[14,15,16]$. The results of the heavy metal analysis on the core samples from the study area are given in Tables 2 and 3.

Table 2. Heavy metal consantrations of core samples

\begin{tabular}{|l|c|c|c|c|c|c|c|c|}
\hline $\begin{array}{l}\text { Sample } \\
\text { No }\end{array}$ & $\begin{array}{c}\mathbf{Z n} \\
(\mathbf{m g} / \mathbf{L})\end{array}$ & $\begin{array}{c}\mathbf{M n} \\
(\mathbf{m g} / \mathbf{L})\end{array}$ & $\begin{array}{c}\mathbf{A s} \\
(\mathbf{m g} / \mathbf{L})\end{array}$ & $\begin{array}{c}\mathbf{B} \\
(\mathbf{m g} / \mathbf{L})\end{array}$ & $\begin{array}{c}\mathbf{C o} \\
(\mathbf{m g} / \mathbf{L})\end{array}$ & $\begin{array}{c}\mathbf{C r} \\
(\mathbf{m g} / \mathbf{L})\end{array}$ & $\begin{array}{c}\mathbf{C u} \\
(\mathbf{m g} / \mathbf{L})\end{array}$ & $\begin{array}{c}\mathbf{N i} \\
(\mathbf{m g} / \mathbf{L})\end{array}$ \\
\hline Core-1 & 80.8 & 1874.4 & 22.3 & 36.12 & 84.12 & 88.20 & 26.57 & 232.86 \\
\hline Core-2 & 91.3 & 619.2 & 25.5 & 40.54 & 91.14 & 92.34 & 29.12 & 236.19 \\
\hline Core-3 & 104.5 & 513.7 & 18.4 & 44.27 & 93.42 & 97.55 & 33.34 & 246.52 \\
\hline Core-4 & 191.7 & 420.8 & 21.78 & 42.81 & 43.72 & 47.83 & 26.77 & 131.62 \\
\hline Core-5 & 253.2 & 422.9 & 18.6 & 43.79 & 52.66 & 52.34 & 19.24 & 134.86 \\
\hline Core-6 & 265.4 & 514.6 & 23.4 & 52.29 & 63.78 & 79.44 & 24.69 & 158.34 \\
\hline Core-7 & 99.4 & 367.6 & 20.6 & 80.80 & 65.92 & 46.90 & 14.56 & 76.44 \\
\hline Core-8 & 97.5 & 336.6 & 22.8 & 66.60 & 74.49 & 56.22 & 17.55 & 76.79 \\
\hline Core-9 & 62.9 & 283.7 & 24.82 & 63.81 & 43.18 & 27.54 & 13.98 & 43.25 \\
\hline Core-10 & 118.4 & 366.4 & 78.9 & 65.82 & 73.48 & 48.66 & 29.48 & 69.93 \\
\hline
\end{tabular}

Since the concentrations of $\mathrm{Na}, \mathrm{Ca}, \mathrm{Mg}, \mathrm{K}, \mathrm{Al}$ and $\mathrm{Fe}$ in the elements were much higher than those of the other elements, they could not be evaluated in the same graph. Therefore, concentration values of the elements ( $\mathrm{Zn}, \mathrm{Mn}, \mathrm{As}, \mathrm{B}, \mathrm{Co}, \mathrm{Cr}, \mathrm{Cu}, \mathrm{Ni}, \mathrm{Sb}, \mathrm{P}, \mathrm{Pb}, \mathrm{Hg}, \mathrm{Cd}, \mathrm{Ag}, \mathrm{Bi}$, $\mathrm{Cd}, \mathrm{Mo}, \mathrm{Pb}, \mathrm{Pt}, \mathrm{Sn}, \mathrm{Se}, \mathrm{Hg}$ ) except for $\mathrm{Na}, \mathrm{Ca}, \mathrm{Mg}, \mathrm{K}, \mathrm{Al}$ and $\mathrm{Fe}$ are given in Figure 2. In the graph, it is seen that the Mn values in Kor 1 (Bandirma) are several times higher than the other elements. This area is an important finding in terms of ship transportation and industrial activities. 
Table 3. Heavy metal concentrations of core samples (Continous of Table 2)

\begin{tabular}{|l|c|c|c|c|c|c|c|c|}
\hline Sample & $\begin{array}{c}\mathbf{S b} \\
(\mathbf{m g} / \mathbf{L})\end{array}$ & $\begin{array}{c}\boldsymbol{P} \\
(\mathbf{m g} / \mathbf{L})\end{array}$ & $\begin{array}{c}\mathbf{A l} \\
(\mathbf{m g} / \mathbf{L})\end{array}$ & $\begin{array}{c}\mathbf{F e} \\
(\mathbf{m g} / \mathbf{L})\end{array}$ & $\begin{array}{c}\mathbf{N a} \\
(\mathbf{m g} / \mathbf{L})\end{array}$ & $\begin{array}{c}\mathbf{M g} \\
(\mathbf{m g} / \mathbf{L})\end{array}$ & $\begin{array}{c}\boldsymbol{K} \\
(\mathbf{m g} / \mathbf{L})\end{array}$ & $\begin{array}{c}\mathbf{C a} \\
(\mathbf{m g} / \mathbf{L})\end{array}$ \\
\hline Core-1 & 2.36 & 436.60 & 24521.9 & 38778.80 & 2648.67 & 5157.36 & 3232.47 & 62475.50 \\
\hline Core-2 & 3.88 & 427.54 & 26693.6 & 39754.10 & 3336.44 & 5345.23 & 3954.25 & 22870.00 \\
\hline Core-3 & 2.69 & 472.13 & 27784.3 & 42559.02 & 3852.60 & 5652.67 & 4332.46 & 16986.60 \\
\hline Core-4 & 2.38 & 417.40 & 15697.3 & 29419.51 & 3055.90 & 3777.12 & 1836.25 & 93491.20 \\
\hline Core-5 & 2.79 & 398.55 & 19560.7 & 29875.04 & 3387.00 & 4116.18 & 2769.82 & 78905.70 \\
\hline Core-6 & 3.83 & 444.62 & 20416.3 & 35658.44 & 3871.15 & 4669.63 & 3635.15 & 90172.90 \\
\hline Core-7 & 2.45 & 404.42 & 26953.7 & 34662.57 & 7945.75 & 5741.70 & 7126.61 & 38647.10 \\
\hline Core-8 & 3.38 & 541.02 & 27588.9 & 36925.37 & 6226.51 & 5547.23 & 6865.53 & 44717.40 \\
\hline Core-9 & 2.49 & 318.66 & 19592.1 & 24879.81 & 6777.15 & 4388.74 & 4327.36 & 82879.86 \\
\hline Core-10 & 6.68 & 710.18 & 27531 & 41768.10 & 7548.63 & 4834.22 & 5036.50 & 14287.50 \\
\hline
\end{tabular}

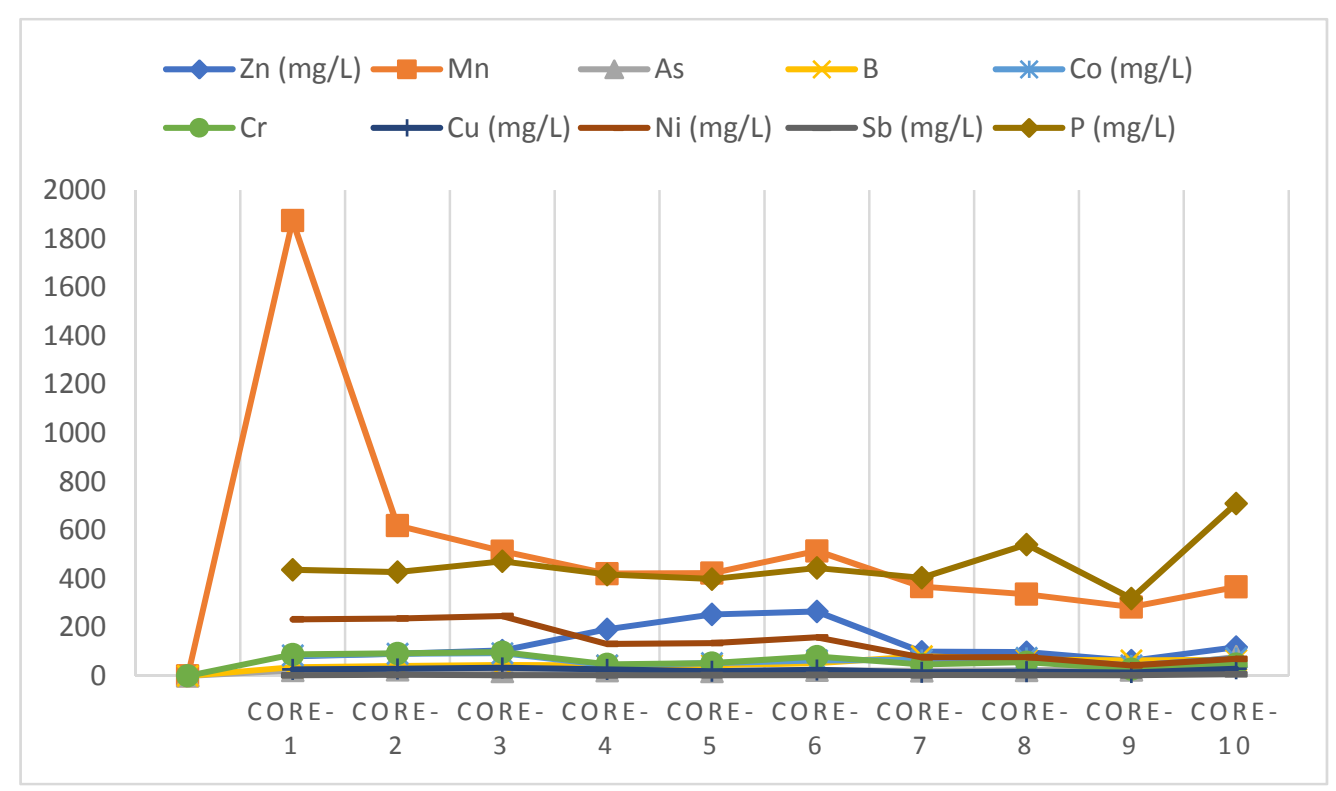

Figure 2. Heavy metal concentrations of core samples

Furthermore, the fact that $\mathrm{Mn}$ and $\mathrm{P}$ values are high in all locations indicates agricultural activities. 
Table 4. Minimum and maximum metal values and mean shale values measured in the sediment (Şener, 2010)

\begin{tabular}{|l|c|c|c|c|c|c|c|c|}
\hline & $\mathbf{C u}$ & $\mathbf{Z n}$ & $\mathbf{F e}$ & $\mathbf{C o}$ & $\mathbf{C r}$ & $\mathbf{P b}$ & $\mathbf{M n}$ & $\mathbf{N i}$ \\
\hline $\begin{array}{l}\text { Min } \\
\text { values }\end{array}$ & 13.98 & 62.9 & 24879.81 & 43.18 & 27.54 & 0 & 283.7 & 43.25 \\
\hline $\begin{array}{l}\text { Max } \\
\text { values }\end{array}$ & 29.48 & 265.4 & 42559.02 & 93.42 & 97.55 & 0 & 1874.4 & 246.52 \\
\hline $\begin{array}{l}\text { Mean } \\
\text { values }\end{array}$ & 45 & 95 & $\begin{array}{c}47000- \\
48000\end{array}$ & 19 & 90 & 20 & 850 & 68 \\
\hline
\end{tabular}

\section{Results}

As a result of heavy metal analysis; $\mathrm{Ag}, \mathrm{Bi}, \mathrm{Cd}, \mathrm{Mo}, \mathrm{Pb}, \mathrm{Pt}, \mathrm{Sn}, \mathrm{Se}, \mathrm{Hg}$ elements were measured as $0 \mathrm{mg} / \mathrm{L}$. Comparing the results of the analysis with the World Average Shale Values, maximum values for $\mathrm{Ni}, \mathrm{Mn}, \mathrm{Cr}, \mathrm{Zn}$ and $\mathrm{Co}$ were above the World average values. Maximum and minimum $\mathrm{Pb}, \mathrm{Cu}$ and $\mathrm{Fe}$ values are below the mean shale values. The Co concentration was determined above the mean values for both values. Also, the concentrations of heavy metals in the samples taken from the Kor-9 site were at the lowest values compared to other locations. In Kor-9, there is no industrial infrastructure and port management, and it is used as a beach area. Therefore, the area is not affected by polluting elements.

In addition to domestic and industrial inputs, an important input of metals such as $\mathrm{Pb}, \mathrm{Zn}, \mathrm{As}$, $\mathrm{Mo}, \mathrm{Ni}, \mathrm{Cr}$ and $\mathrm{W}$ to the southern shelves and bays of the Marmara Sea has also been found in various metal mineralizations and high background values in the southern drainage basin of the Marmara Sea, containing mafic, utramafic and granitic rocks. Both the abrasive products of these mineralizations and the lithophyll elements, such as $\mathrm{K}, \mathrm{Rb}, \mathrm{Li}, \mathrm{La}$ and $\mathrm{Nb}$, are transported to the southern shelf region as a largely suspended mineral crumb material by Kocasu, Gönen and Biga rivers, and are distributed distributed to the outer shelf and deep zone regions by the flow system [17]. In addition, the excess fertilizer and pesticides remaining in the soil carried by Kocasu, Gönen and Biga rivers in areas where the agricultural activities are concentrated contribute to the heavy metal pollution that occurs in the study area.

\section{Acknowledgements}

The author thanks Sevinç Yümün for the preparation of the samples in the laboratory and also for the separation studies of other fossils.

The author also thanks Yildiz Technical University Scientific Research Projects Commission for accepting and financing this study (Project no: 2015-01-01-KAP01).

\section{References}

[1] Köleli, N., Kantar, Ç, "Fosfat kayası, Fosforik Asit ve Fosforlu Gübrelerdeki Toksik Ağır Metaller (Cd, $\mathrm{Pb}, \mathrm{Ni}, \mathrm{As}) \quad$ Konsantrasyonu” Journal of Ecology 14(55) (2005).

[2] Önce, M., “Güre (Edremit/Balıkesir) ile Küçükkuyu (Ayvacık/Çanakkale) Arasında Ege Denizi'ndeki Ağır Metal Kirliliğinin Yayılımı ve Foraminiferler Üzerindeki Etkilerinin 
Araştırılması." (Namık Kemal University, Institute of Science and Technology. Graduate Thesis. 88,2014).

[3] Rether, A., "Entwicklung und Charakterisierung wasserlöslicher Benzoylthioharnstofffunktionalisierter Polymere zur selektiven Abtrennung von Schwermetallionen aus Abwässern und Prozesslösungen. " (Munich Technical University. Doctoral Thesis,2002).

[4] Meriç, E., Avşar, N., Nazik, A., Yokeş, B., Dora, Ö., Barut, İ. F., Eryılmaz, M., Dinçer, F., Kam, E., Aksu, A., Taşkın, H., Başsarı, A., Bircan, C., Kaygun, A., "Karaburun Yarımadası Kuzey Kıyılarının Oşinografik Özelliklerinin Bentik Foraminifer ve Ostrakod Toplulukları Üzeindeki Etkileri. ” Journal of Mine Investigation Search 145 (2012): 22-47.

[5] Mülayim, A., Arısal, S. B., Balkıs, H., "Kapıdă̆ Yarımadası (Marmara DEnizi) Yüzey Sediment Örneklerinde Toplam Organik ve İnorganik Karbon Düzeylerinin Belirlenmesi" (paper presented at the annual meeting for the 21. National Biology Congress. Ege University, 2012).

[6] Algan, O., Çağatay, N., Sarıkaya, H.Z., Balkıs, N., Sarı, E., "Pollution monitoring using marine sediments: A case study on the Istanbul metropolitan area." Tr. J. Eng. Sci. 23 (1999): 39-48.

[7] Yümün, Z. Ü., "The Effects of Heavy Metal Concentrations in the Çanakkale Strait (Turkey): Morphological Differences in the Holocene Foraminiferal Assemblages." Journal of Engineering Technology and Applied Sciences. 1(2) (2016): 77-88.

[8] Balkıs, N., Çağatay M. N., "Factors Controlling Metal Distributions In The Surface Sediments Of The Erdek Bay, Sea Of Marmara" Turkey. Environment International 27(1) (2001): 1-13.

[9] Erdoğan, M., "Monitoring and Statıstıcal Assessment of Heavy Metal Pollution in Sediments Along İzmir Bay Using İCP-MS" (The Graduate School of Engineering and Sciences of İzmir Institute of Technology Doctorate Thesis. İzmir.109, 2009).

[10] Yümün, Z.Ü., Meriç, E., Avşar, N., Nazik, A., Barut, I.F., Yokeş, B., Sagular, E.K., Yıldız, A., Eryılmaz, M., Kam, E., Başsarı, A., Sonuvar, B., Dinçer, F., Baykal, K., Kaya, S., "Meiofauna, Microflora And Geochemical Properties Of The Late Quaternary (Holocene) Core Sediments In The Gulf Of Izmir (Eastern Aegean Sea, Turkey) " Journal of African Earth Sciences - Elsevier 124 (2016): 383-408.

[11] Ünsal, M., Çağatay, N., Bekiroğlu, Y., Kıratlı, N., Alemdağ, N., Aktaş, M., Sarı, E., “Karadeniz'de Ağır Metal Kirliliği. Ministry of Agriculture and Rural Affairs General Directorate of Agricultural Research Marine Sciences Institute, Erdemli, İçel and Fisheries Research Institute. Yomra, Trabzon.” Project number: Ydebçag-456/G-457/G, 1998.

[12] Yümün, Z. Ü., Kam, E., Önce, M., Yümün, S., Açıkgöz, G., “Stratigraphic and Geochemical Characteristics of Kulakçayırı Lake (İstanbul/Türkey) and Its Vicinity." Journal of Engineering Technology and Applied Sciences 1(1) (2016b): 1-12.

[13] Sağlam, M. T., Bellitürk, K., Hazinedar, N., Danışman, F. "Kapıdă̆ Yarımadası Zeytinliklerinin Beslenme Durumu." Journal of Selçuk University Agricultural Faculty .22(44) (2008): 118-123. 
[14] Artüz, İ., Baykut, F., "Marmara Denizi’nin Hidrografisi Ve Su Kirlenmesi Açısından Bilimsel Etüdü..” Istanbul University Environmental Problems Application and Research Center Publications, 9, 1989.

[15] Tunoğlu, C., "Recent Ostracoda association in the Sea of Marmara. Earth Sciences" (21) (1999): 63- 89.

[16] Avşar, N., Aksu, A., Dinçer, F., “Erdek Körfezi’nde (GB Marmara Denizi) Bentik Formainifer Topluluklar1.” Journal of Hacettepe University Geoscience Application and Research Center 27(3) (2006): 125-141.

[17] Çağatay, N., Balkis N., Sancar Ü., Çakır Z., Yücesoy Eryılmaz F., Eryılmaz M., Sari E., Akçer S., Biltekin D., "Marmara Denizi Çökel Jeokimyası Atlası.” 60. Geological Congress of Turkey, Ankara, Türkiye. (2007): 350-351. 